\title{
Towards a Miniaturized Culture Screening for Cellulolytic Fungi and Their Agricultural Lignocellulosic Degradation
}

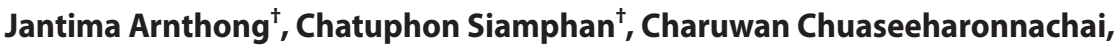 \\ Nattawut Boonyuen, and Surisa Suwannarangsee* \\ National Center for Genetic Engineering and Biotechnology (BIOTEC), National Science and Technology \\ Development Agency (NSTDA), 113 Thailand Science Park, Klong Luang, Pathumthani 12120, Thailand
}

\begin{abstract}
The substantial use of fungal enzymes to degrade lignocellulosic plant biomass has widely been attributed to the extensive requirement of powerful enzyme-producing fungal strains. In this study, a two-step screening procedure for finding cellulolytic fungi, involving a miniaturized culture method with shake-flask fermentation, was proposed and demonstrated. We isolated 297 fungal strains from several cellulose-containing samples found in two different locations in Thailand. By using this screening strategy, we then selected 9 fungal strains based on their potential for cellulase production. Through sequence-based identification of these fungal isolates, 4 species in $\mathbf{4}$ genera were identified: Aspergillus terreus (3 strains: AG466, AG438 and AG499), Penicillium oxalicum (4 strains: AG452, AG496, AG498 and AG559), Talaromyces siamensis (1 strain: AG548) and Trichoderma afroharzianum (1 strain: AG500). After examining their lignocellulose degradation capacity, our data showed that $P$. oxalicum AG452 exhibited the highest glucose yield after saccharification of pretreated sugarcane trash, cassava pulp and coffee silverskin. In addition, Ta. siamensis AG548 produced the highest glucose yield after hydrolysis of pretreated sugarcane bagasse. Our study demonstrated that the proposed two-step screening strategy can be further applied for discovering potential cellulolytic fungi isolated from various environmental samples. Meanwhile, the fungal strains isolated in this study will prove useful in the bioconversion of agricultural lignocellulosic residues into valuable biotechnological products.
\end{abstract}

Keywords: Lignocellulosic biomass, microplate-based screening, enzymatic saccharification, cellulase, hemicellulase, fungal degradation

Received: July 6, 2020 Accepted: August 25, 2020

First published online: August 27, 2020

*Corresponding author Phone: $+66-25646700$ Fax: +66-2564-6700

E-mail:surisa.suw@biotec.or.th

These authors contributed equally to this work.

Supplementary data for this paper are available on-line only at http://jmb.or.kr.

pISSN 1017-7825 elSSN 1738-8872

Copyright(C) 2020 by The Korean Society for Microbiology and Biotechnology

\section{Introduction}

The significant global concern regarding carbon dioxide $\left(\mathrm{CO}_{2}\right)$ emissions from the combustion of fossil fuels into the atmosphere has promoted the use of biofuel-derived biomass feedstock as an eco-friendly, alternative energy source $[1,2]$. The utilization of waste biomass is not only a carbon neutral process but such resources can also be considered inexpensive, abundant and sustainable [3]. Lignocellulosic biomasses, i.e., sugarcane bagasse and trash and wheat straw and rice straw, can be used to produce a wide range of biobased chemicals used in biofuels and construction $[4,5]$. The integration of lignocellulosic residues into the circular economy can scale up sustainable bioproducts, bioenergy development and biotechnological interest [6-8].

Lignocellulosic feedstocks mainly comprise cellulose, hemicellulose, and lignin, which form their rigid structure [9]. The composition of lignocellulose is diverse depending on the plant species, growth condition and age [10]. Basically, physicochemical pretreatment, recalcitrant structure disruption and enzymatic saccharification steps are required for the transformation of lignocellulosic biomass into fermentable sugars, which can then be further converted to biofuel or other value-added chemicals [11]. Cellulases are a group of enzymes that catalyze cellulose as a major component of lignocellulose in which it breaks the 1,4- $\beta$-glycosidic bonds within the cellulose chain of lignocellulosic biomass into glucose subunits [12]. Cellulases consist of three enzymes: endoglucanase (EG; E.C. 3.2.1.4), cellobiohydrolase (CBH; E.C. 3.2.1.91), and $\beta$-glucosidase (BGL; E.C. 3.2.1.21), which act synergistically in cellulose hydrolysis [13]. Additionally, the action of endoxylanase (E.C.3.2.1.8) and $\beta$-xylosidase (E.C.3.2.1.37) is essential for the hydrolysis of xylan as the second most abundant polysaccharide in lignocellulosic materials [14]. Cooperative digestion of cellulases and hemicellulases is required for efficient hydrolysis of lignocellulose $[15,16]$. Even though the preparation of commercial cellulase supplemented with hemicellulase is available on the market, significant research efforts are still focused on finding a novel cellulase cocktail $[17,18]$. This might be due to the cost of enzymes and the heterogeneity of lignocellulosic substrates, resulting in single- 


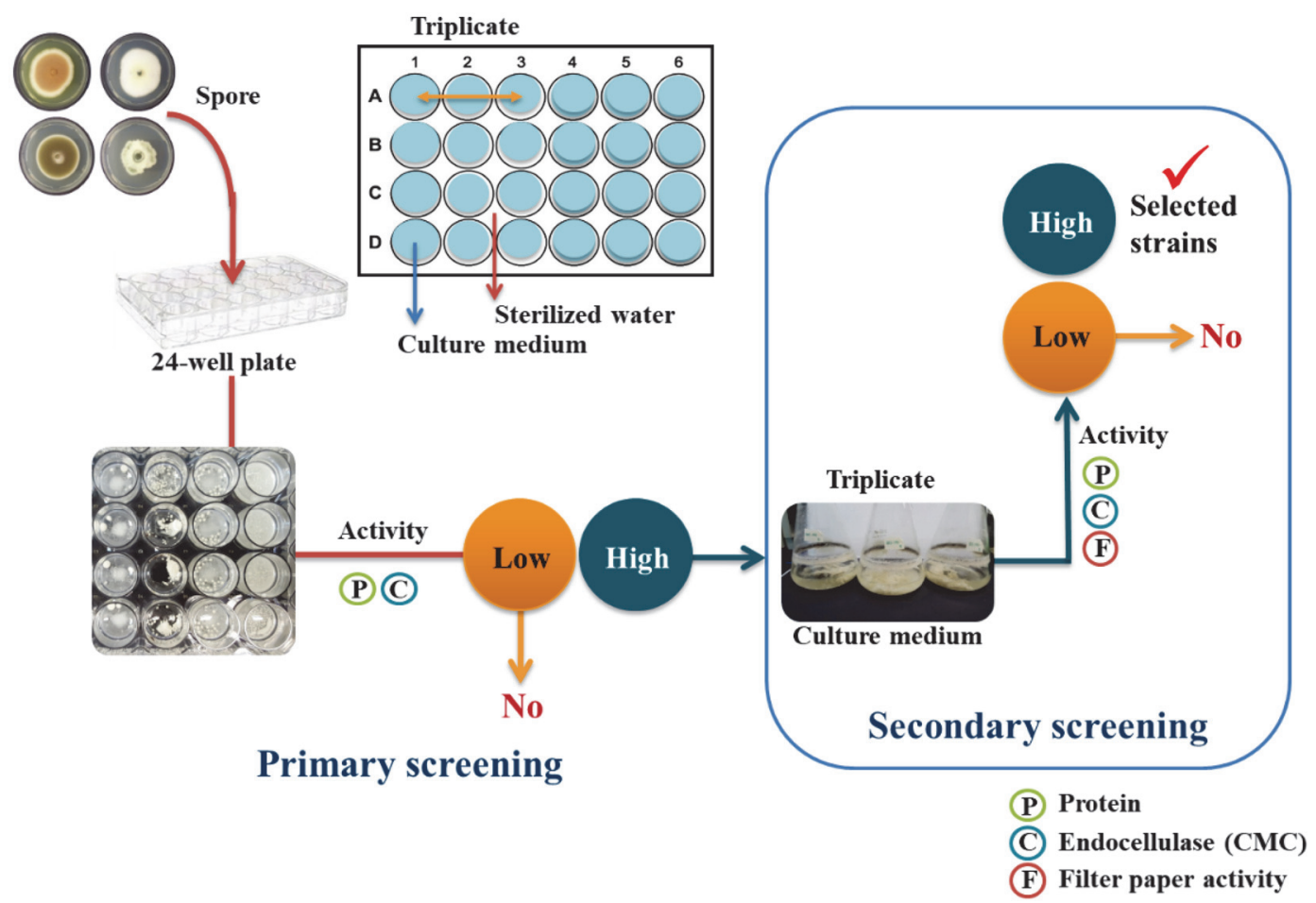

Fig. 1. Schematic of the screening workflow for cellulolytic fungi. Two proposed steps: (1) preliminary screening using a microplate-based cultivation step; (2) secondary screening using shake-flask cultivation.

enzyme cocktails being unsuitable for all applications [19]. Finding an ideal microbial strain that produces an efficient enzyme cocktail capable of reducing the cost of enzymes and consequently the cost of biomass saccharification is still a challenging task [20].

Cellulases can be produced by several types of microorganisms, including bacteria and fungi [21]. For example, fungal genera, i.e., Trichoderma, Penicillium, Aspergillus and Talaromyces, have been proven to be better candidates for cellulase production than other microbial species since these fungi can secrete large amounts of cellulases and hemicellulases [22]. The conventional technique for primarily screening potential high cellulase producers is the agar-plate method, in which cellulosic material is added into an agar plate as a selective carbon source [23]. However, the context of screening from a large number of fungal strains using the agar-plate screening technique is limited, laborious and time consuming. Recently, different high-throughput screening platforms for filamentous fungi have been developed, ranging from the utilization of robotic machines to droplet-based microfluidic technology [24, 25]; nevertheless, these expensive instruments cannot possibly be installed in all laboratories.

A miniaturized culture method that scales down the fermentation volume into a 24 -well microtiter plate has been reported to efficiently reduce labor and facilitate experiments with a large number of fungal strains [26]. This method was successfully demonstrated in solid cultivation of Trichoderma strains for screening of cellulase activity [11], screening of $A$. carbonarius for citric acid production [26] and screening of A. terreus mutants for itaconic acid production [27]. In this study, we applied the 24-well plate culture technique to discover natural fungal strains with cellulose degradation capabilities, as summarized in Fig. 1. Cellulolytic fungi were isolated from various lignocellulosic samples collected from two selected different areas in Thailand. For the first screening step, these fungi were primarily assessed for their cellulase activities by a microplate-based culture method that mimics shake-flask conditions. For the second step, selected fungal strains were subsequently screened by shake-flask fermentation. Additionally, potential cellulase-producing strains were identified using DNA sequencing of the nrDNA internal transcribed spacer (ITS) region. To support ITS data and for use as additional molecular fungal markers, loci of $C a M, T E F 1 \alpha, R P B 2$ and other regions were also employed for further identification. Finally, their secreted enzymes based on the hydrolysis of different agro-industrial residues into simple fermentable sugars were evaluated.

\section{Materials and Methods}

\section{Sampling and Isolation of Cellulolytic Fungi}

Twenty-two samples of various cellulose-containing substrates, including rice husks, rice husk ash, dried butterfly peas, dried banana stems, organic fertilizer, plant debris, manure, soil, and vermicompost, were randomly collected from two selected locations in Thailand: 1) Rural Farming Happiness Center, Mueang Ratchaburi district, Ratchaburi Province $\left(13^{\circ} 27^{\prime} \mathrm{N}, 99^{\circ} 45^{\prime} \mathrm{E}\right)$ and 2$)$ Tha Makham Natural Farming Center, 
Mueang Kanchanaburi district, Kanchanaburi Province $\left(14^{\circ} 31^{\prime} \mathrm{N}, 99^{\circ} 29^{\prime} \mathrm{E}\right)$. All samples were transferred to the laboratory at BIOTEC and maintained at $4^{\circ} \mathrm{C}$ in a refrigerator.

Modified Czapek-Dox's agar medium supplemented with 1\% (w/v) carboxy-methyl cellulose (CMC) as the sole carbon source was applied to isolate cellulose-degrading fungi. This modified medium contained the following (g/l): $\mathrm{CMC}, 10.0 ; \mathrm{NaNO}_{3}, 2.0 ; \mathrm{K}_{2} \mathrm{HPO}_{4}, 1.0 ; \mathrm{MgSO}_{4}, 0.5 ; \mathrm{KCl}, 0.5 ; \mathrm{FeSO}_{4}, 0.01$; and agar, 15.0 (pH 6.8). Rose bengal (Sigma-Aldrich, Spain) and $30 \mathrm{ppm}$ streptomycin sulfate (BIO Basic, Markham, Canada) were added to the modified medium. Fungal strains were isolated on the modified media plates and incubated at room temperature $\left(\sim 25-28^{\circ} \mathrm{C}\right)$ until fungal appearance. Distinct fungal colonies with different morphological forms, i.e., colony color, texture and margins, were subcultured and preserved on potato dextrose agar (PDA) plates for further studies.

\section{Primary Screening by a Microplate-Based Method}

The miniaturized culture system was carried out in a 24-well plate (Nest Biotechnology, China). The diameter of each well was $1.9 \mathrm{~cm}^{2}$ with a working volume of $1 \mathrm{ml}$ per well. Spores of each fungal isolate were prepared by a five-day cultivation on PDA plates at $30^{\circ} \mathrm{C}$. Then, fungal spores were inoculated using a sterile disposable toothpick to transfer every strain into the 24-well plate containing $1 \mathrm{ml}$ of the screening medium in each well. Mandels and Weber medium (MM; [28]), containing 1\% Avicel as the sole carbon source, was applied as a screening medium. The 24 -well culture plates were installed in plate stacks and then incubated at $30^{\circ} \mathrm{C}$ and $250 \mathrm{rpm}$ for 7 days. An amount of sterilized distilled water was added into the free space between well plates to avoid evaporation during the incubation period. The fungal cultures were harvested by centrifugation at $3,000 \times g$ for $10 \mathrm{~min}$ at $4^{\circ} \mathrm{C}$. The enzyme solutions were kept at $4^{\circ} \mathrm{C}$ until further analysis. As in a previous study, A. aculeatus BCC199 was used for comparison as a cellulase-producing reference strain [13].

\section{Secondary Screening through 250-ml Shake-Flask Fermentation}

Based on the primary screening method, cellulase production of selected fungal strains was validated in $250-\mathrm{ml}$ shake flask cultures. Each fungal strain was plated on PDA medium and incubated at $30^{\circ} \mathrm{C}$ for 5 days. Subsequently, spore suspensions were obtained by adding $0.1 \%(\mathrm{v} / \mathrm{v})$ Tween 20 into the PDA plates. The fungal strains $\left(1 \times 10^{8}\right.$ spores) were inoculated into $50 \mathrm{ml}$ of MM medium containing $1 \%$ Avicel as the sole carbon source. The experiment was performed in triplicate and incubated at $30^{\circ} \mathrm{C}$ and $200 \mathrm{rpm}$ for 7 days. The crude enzyme products were obtained by centrifugation of the culture at $9,000 \times g$ for $10 \mathrm{~min}$ at $4^{\circ} \mathrm{C}$.

\section{Sequence-Based Identification of Cellulolytic Fungi}

After the primary and secondary screenings, potent fungal strains were identified by molecular data. DNA extraction from a mycelium on PDA was performed using the method described by [29] with some modifications. The gene region of the ITS was sequenced first as a fungal barcoding locus. In case of unsuccessful identification and for supporting ITS data, unidentified fungal strains were further sequenced using one of the additional molecular loci, i.e., translation elongation factor $1 \alpha(T E F-1 \alpha)$, the second largest subunit of RNA polymerase II (RPB2), calmodulin $(C a M)$ or $ß$-tubulin (TUB). PCR products were amplified using the primer pairs ITS5/ITS4 [30], 983F/2218R [31], fRPB2-5F2/fRPB2-7cR [32], cmd5/cmd6 [33] and Bt2a/Bt2b [34]. All PCRs were performed in a Bio-Rad T100 Thermal Cycler (Bio-Rad, Hercules, CA, USA) according to conditions described by [35]. DNA sequencing was performed with the primers mentioned above at Macrogen Inc. (Korea). Sequences were analyzed by BioEdit v7.0.5.3 [36] and run through a standard nucleotide BLAST (Basic Local Alignment Search Tool; NCBI nucleotide database; http://www.ncbi.nlm.nih.gov/) to evaluate the similarity with reported sequences of fungal species. Fungal sequences were then analyzed by comparison with the type species sequences. All new fungal sequences were deposited in the NCBI database under the accession numbers shown in Table S1.

\section{Production of Cellulases in Submerged Fermentation}

The selected fungal strains were cultivated under submerged fermentation in 250-ml shake flasks containing $50 \mathrm{ml}$ of production medium. The production medium $(1 \mathrm{~L})$ was composed of the following: Avicel, $10 \mathrm{~g}$; wheat bran, $25 \mathrm{~g} ; \mathrm{KH}_{2} \mathrm{PO}_{4}, 2 \mathrm{~g} ; \mathrm{CaCl}_{2} \cdot 2 \mathrm{H}_{2} \mathrm{O}, 0.3 \mathrm{~g}$; urea $0.3 \mathrm{~g} ; \mathrm{MgSO}_{4} \cdot 7 \mathrm{H}_{2} \mathrm{O}, 0.3 \mathrm{~g} ;\left(\mathrm{NH}_{4}\right)_{2} \mathrm{SO}_{4}, 1.4 \mathrm{~g} ; \mathrm{FeSO}_{4} \cdot 7 \mathrm{H}_{2} \mathrm{O}, 0.005 \mathrm{~g}$; $\mathrm{MnSO}_{4} \cdot \mathrm{H}_{2} \mathrm{O}, 0.0016 \mathrm{~g} ; \mathrm{ZnSO}_{4} \cdot 7 \mathrm{H}_{2} \mathrm{O}, 0.0014 \mathrm{~g} ; \mathrm{CoCl}_{2} \cdot 2 \mathrm{H}_{2} \mathrm{O}, 0.002 \mathrm{~g}$; peptone, $0.25 \mathrm{~g}$; yeast extract, $0.1 \mathrm{~g}$; and Tween, $800.1 \mathrm{~g}$ [37]. Each flask was inoculated with $5 \times 10^{6}$ spores $/ \mathrm{ml}$ spore suspension and incubated at $30^{\circ} \mathrm{C}$ under shaking at $200 \mathrm{rpm}$ for 7 days. After cultivation, the solid part containing fungal mycelia and insoluble materials was removed by filtration through a nylon cloth, followed by centrifugation at $9,000 \mathrm{rpm}$ and $4^{\circ} \mathrm{C}$ for $10 \mathrm{~min}$. The crude enzyme solution was evaluated for enzyme activities and used for biomass saccharification experiments. All fungal cultivations were performed in triplicate.

\section{Enzymatic Saccharification of Agricultural Residues}

All lignocellulosic materials, sugarcane trash (ST), sugarcane bagasse (BG), cassava pulp (CP) and coffee silver skin (SS), were locally obtained from selected sites located in Thailand. The biomass was physically processed using a cutting mill (Retsch SM2000, Germany) and sieved to particles $250-420 \mu \mathrm{m}$ in size. Before hydrolysis, the lignocellulosic materials were pretreated by a two-stage integrated process [38]. In the first step, each agricultural residue was pretreated with diluted sulfuric acid $(1 \% \mathrm{v} / \mathrm{v})$ with a solid:liquid ratio of $1: 2$ at $121^{\circ} \mathrm{C}$ for 45 min to hydrolyze hemicellulose. For the second step, a $4 \%(\mathrm{w} / \mathrm{v})$ sodium hydroxide solution was applied to degrade lignin at a solid:liquid ratio of $1: 20$, followed by heating at $121^{\circ} \mathrm{C}$ for $30 \mathrm{~min}$. Then, the solid fraction was separated and washed with tap water until the $\mathrm{pH}$ was 7 . The pretreated biomasses were dried at $70^{\circ} \mathrm{C}$ before enzymatic 
hydrolysis. Chemical compositions (percentage of cellulose, hemicelluloses and lignin) were analyzed using the standard NREL method [39].

For the enzymatic hydrolysis experiment, $5 \%(\mathrm{w} / \mathrm{v})$ of pretreated biomass (ST, BG, CP or SS) was subjected to a $10-\mathrm{ml}$ reaction consisting of $7.5 \mathrm{mg}$ protein/g biomass crude enzyme, $50 \mathrm{mM}$ sodium acetate buffer at $\mathrm{pH} 5.0$, and $0.1 \%(\mathrm{v} / \mathrm{v})$ sodium azide. The reaction was incubated at $50^{\circ} \mathrm{C}$ with shaking at $200 \mathrm{rpm}$ for $72 \mathrm{~h}$. The hydrolysate was centrifuged at 9,000 rpm for $10 \mathrm{~min}$, and the supernatant was collected to analyze the released reducing sugar concentration using the 3,5-dinitrosalicylic acid (DNS) method [40]. The fermentable sugar profiles were analyzed via high-performance liquid chromatography (HPLC). The experiments were performed in quadruplicate.

\section{Determination of Enzyme Activity}

The activity of total cellulases (FPase) was determined based on the International Union of Pure and Applied Chemistry (IUPAC) method using Whatman No. 1 filter paper as a substrate [41]. The reaction mixture was incubated at $50^{\circ} \mathrm{C}$ for $60 \mathrm{~min}$. For CMCase and xylanase activities, enzymatic assays were conducted in a reaction mixture comprising $50 \mathrm{mM}$ sodium acetate buffer ( $\mathrm{pH}$ 5.0) using $1 \%(\mathrm{w} / \mathrm{v}) \mathrm{CMC}$ and $1 \%(\mathrm{w} / \mathrm{v})$ xylan from beech wood as the substrate. The amount of reducing sugar was quantified according to the DNS method [40]. One enzymatic activity unit $(\mathrm{U})$ was defined as the amount of enzyme required to release $1 \mu \mathrm{mol}$ of glucose or xylose per minute under the assay conditions. For determination of $\beta$-glucosidase (BGL) and $\beta$-xylosidase (BX) activity, $40 \mathrm{mM} p$-nitrophenyl- $\beta$-D-glucopyranoside ( $p$ NPG; Sigma) and $p$-nitrophenyl- $\beta$-D-xylopyranoside ( $p N P X$; Sigma) were applied as the substrates, respectively. The assays were performed as previously described [13]. One BGL or BX activity $U$ was defined as the amount of enzyme that liberated $1 \mu \mathrm{mol}$ of $p$-nitrophenol per minute under the assay conditions. The total protein content was determined by using Bradford's method with the BioRad protein assay reagent (Bio-Rad, USA) and bovine serum albumin (BSA) as a standard protein. All experiments were performed in triplicate.

For the primary screening step, determination of cellulase activity (CMCase) was adapted by using a polypropylene 96-well microplate (Eppendorf, Germany). The small-scale assay was performed with a reaction mixture containing $10 \mu \mathrm{l}$ of enzyme sample and $64 \mu \mathrm{l}$ of $2 \%(\mathrm{w} / \mathrm{v}$ ) CMC in $50 \mathrm{mM}$ sodium acetate buffer (pH 5.0). After incubation at $50^{\circ} \mathrm{C}$ for $20 \mathrm{~min}, 126 \mu \mathrm{l}$ of DNS solution was added to the reaction, and then the plate was placed in a water bath $\left(90^{\circ} \mathrm{C}\right)$ for $10 \mathrm{~min}$. Subsequently, the plate was placed on ice for $10 \mathrm{~min}$. One hundred microliters were transferred into a new 96-well plate. The absorbance was measured on a microtiter plate reader at a wavelength of $540 \mathrm{~nm}$.

\section{Results and Discussion}

Isolation and Preliminary Screening of Cellulase-Producing Fungal Strains

A total of 297 fungal strains were isolated and cultivated on the 24 -well plate in the small-scale assay. As shown in Fig. 2, most fungal isolates were able to secrete cellulases, and total protein contents were lower or comparable to that of A. aculeatus BCC199 as a reference strain (black border dot; [13]). To isolate and screen potential cellulaseproducing strains, primary screening on solid agar plates might not guarantee enzyme production when compared with liquid-stage culture screening. Most industrial enzyme production has been performed under



Fig. 2. Scatter plot representing CMCase activity using a small-scale assay and the amount of secreted protein of different fungal strains based on a microplate-based screening assay. A. aculeatus BCC199 (reference strain; black border dot), selected strains (black dot), non-selected strains (gray dot) are shown. 
submerged cultivation [42]. Hence, it is essential to mimic large-scale experiments and simulate the culture conditions of submerged fermentation to discover potent fungal candidates. A 24-well microplate cultivation experiment was carried out to establish and screen a large number of fungal isolates in this study. With respect to finding the maximum cellulase producers, we selected 45 fungal strains (black dot) out of 297 strains because they presented higher cellulase activities and/or protein contents than those of A. aculeatus BCC199. These fungi accounted for $15 \%$ of the total number of fungal isolates.

\section{Secondary Screening of Cellulase-Producing Fungal Strains}

To validate the preliminary screening step, 45 fungal isolates were inoculated in the same medium, but we scaled up the culture size to $50 \mathrm{ml}$ in 250-ml shake flasks together with A. aculeatus BCC199 as a reference strain [13]. After cultivation, crude enzymes were prepared. Cellulase activities on CMC and filter paper substrate were assessed. As shown in Fig. 3, 18 and 31 strains produced higher CMCase and FPase activities, respectively, than those of A. aculeatus BCC199. Among them, strain AG500 exhibited outstanding cellulase activity and protein production after testing based on both the primary and secondary screening steps. This result indicated that the
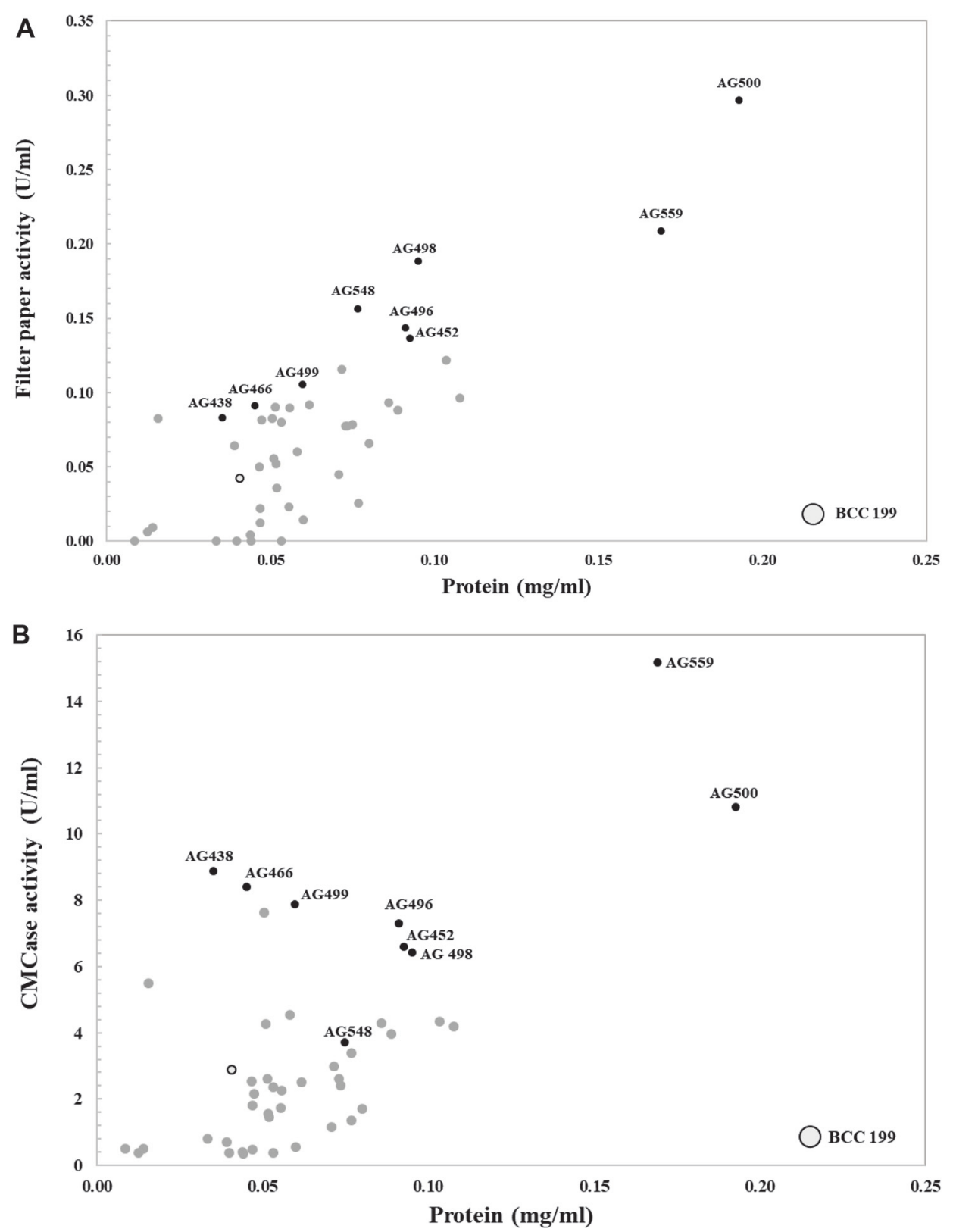

Fig. 3. Scatter plot representing total protein content and cellulase activity against filter paper (FPase; A) and CMC (CMCase; B) as substrates of crude enzymes from selected fungal strains in a 250-ml shake flask. A. aculeatus BCC199 (reference strain; black border dot), selected strains (black dot), nonselected strains (gray dot) are shown. 
pattern of cellulase activity was in accordance with the preliminary screening result. Only 14 strains (31\% of all strains) presented lower cellulase activities or lower protein secretion than those of A. aculeatus BCC199. These data may be due to the powerful microplate-based cultivation approach used in this study. This method may not only quantitatively determine the amount of certain enzyme activities but also eliminate fungal isolates that do not grow well under submerged fermentation conditions. For instance, the microplate-based cultivation method has been implemented successfully, as previously reported in other applications, such as for enzymatic hydrolysis of lignocellulosic biomass according to [43], for mutant archaea and fungal strains using mutagenesis [25, 44] and for fermentation production of citric acid, ethanol and glycerol by filamentous fungi [26].

Based on the secondary screening results, 9 strains out of 45 fungal strains were selected according to the high production level of cellulases (CMCase or FPase). The potential fungal strain numbers were AG438, AG452, AG466, AG496, AG498, AG499, AG500, AG548, and AG559. For CMCase activity, two fungal strains, AG559 and AG500, displayed the highest activities of 15.17 and $10.79 \mathrm{U} / \mathrm{ml}$, respectively, while the reference strain (A. aculeatus BCC199) produced only $2.88 \mathrm{U} / \mathrm{ml}$. Similarly, the highest FPase activities of $0.30 \mathrm{U} / \mathrm{ml}$ and $0.21 \mathrm{U} / \mathrm{ml}$ were produced by AG500 and AG559, respectively. Subsequently, these 9 fungal potential strains were identified using molecular identification and enzyme production. Fungal colonies of these fungal strains are shown in Fig. S1.

\section{Molecular Identification of Selected Cellulase-Producing Fungal Strains}

As shown in Table 1, the BLAST search results of 9 cellulolytic enzyme-producing fungal strains were classified into 4 genera in 4 taxa as follows: A. terreus (AG466, AG438, and AG499), P. oxalicum (AG452, AG496, AG498, and AG559), Ta. siamensis (AG548) and T. afroharzianum (AG500). To our knowledge, this is the first report of cellulase production by $\mathrm{Ta}$. siamensis and T. afroharzianum and on their ability to degrade lignocellulose. In addition, two well-known cellulase producers under the same genera, Ta. cellulolyticus and T. reesei, have been formerly reported $[45,46]$. Furthermore, 3 out of these 9 potential strains, A. terreus strains, were found to be fungal risk group strains of biosafety level two (BSL2) based on the Thailand Biosafety Guidelines for Modern Biotechnology and Fungal Risk Assessment Reports (http://www.biotec.or.th/biosafety/;[47]). As a consequence, these strains were then excluded from this study to avoid the spreading of spores to indoor and outdoor environments. For subsequent enzyme production, only 6 fungal strains were chosen.

\section{Enzyme Production of Cellulase-Producing Fungal Strains}

The application of cellulolytic microorganisms to cellulosic biomass bioconversion is considered one of the potential sustainable approaches to develop several bioproducts, such as biofuels [48]. The most common filamentous fungal genera for the production of cellulolytic enzymes were Aspergillus, Trichoderma, and Penicillium [49]. In this study, six fungal strains of three genera, Penicillum, Trichoderma, and Talaromyces, were grown under submerged fermentation in 250-ml shake flasks. In the experiment, Avicel and wheat bran were used as two coinducers for cellulolytic enzyme production. The presence of complex cellulose from plant materials such as wheat bran was demonstrated to be more efficient than pure cellulose in inducing the expression of lignocellulose-degrading enzymes [50]. Table 2 shows the enzyme activity profile of crude enzymes obtained after 7 days of cultivation. It was found that all fungal strains secreted higher cellulase activities when grown in a medium supplemented with wheat bran. Similarly, two fungal strains, Penicillium sp. CR-316 and Penicillium sp. CR-313, cultivated in medium containing rice straw as an inducer showed improved cellulase activities [51].

Table 1. Fungal species and isolation information of nine potential fungal taxa based on their cellulolytic enzyme production.

\begin{tabular}{|c|c|c|c|c|}
\hline $\begin{array}{l}\text { Fungal } \\
\text { strain }\end{array}$ & Fungal species & Substrate origin & Collection site & $\begin{array}{c}\text { Biosafety } \\
\text { classification level }^{1}\end{array}$ \\
\hline AG438 & Aspergillus terreus & Organic fertilizer & $\begin{array}{l}\text { Tha Makham Natural Farming } \\
\text { Center, Kanchanaburi Province }\end{array}$ & BSL 2 \\
\hline AG452 & Penicillium oxalicum & Dried butterfly pea & $\begin{array}{l}\text { Tha Makham Natural Farming } \\
\text { Center, Kanchanaburi Province }\end{array}$ & BSL 1 \\
\hline AG466 & A. terreus & Vermicompost & $\begin{array}{l}\text { Tha Makham Natural Farming } \\
\text { Center, Kanchanaburi Province }\end{array}$ & BSL 2 \\
\hline AG496 & P. oxalicum & Dried butterfly pea & $\begin{array}{l}\text { Tha Makham Natural Farming } \\
\text { Center, Kanchanaburi Province }\end{array}$ & BSL 1 \\
\hline AG498 & P. oxalicum & Dried butterfly pea & $\begin{array}{l}\text { Tha Makham Natural Farming } \\
\text { Center, Kanchanaburi Province }\end{array}$ & BSL 1 \\
\hline AG499 & A. terreus & Organic fertilizer & $\begin{array}{l}\text { Tha Makham Natural Farming } \\
\text { Center, Kanchanaburi Province }\end{array}$ & BSL 2 \\
\hline AG500 & Trichoderma afroharzianum & Soil & $\begin{array}{l}\text { Tha Makham Natural Farming } \\
\text { Center, Kanchanaburi Province }\end{array}$ & BSL 1 \\
\hline AG548 & Talaromyces siamensis & Soil & $\begin{array}{l}\text { Tha Makham Natural Farming } \\
\text { Center, Kanchanaburi Province }\end{array}$ & BSL 1 \\
\hline AG559 & P. oxalicum & Rice husk ash & $\begin{array}{l}\text { Tha Makham Natural Farming } \\
\text { Center, Kanchanaburi Province }\end{array}$ & BSL 1 \\
\hline
\end{tabular}

${ }^{1}$ BSL= Biosafety level based on the Thailand Biosafety Guidelines for Modern Biotechnology and Fungal Risk Assessment Report (http://www.biotec.or.th/biosafety/; [47]. 
Table 2. Activity of cellulase and hemicellulase and protein content based on selected fungal strains after cultivation in the production medium.

\begin{tabular}{ccccccc}
\hline \multirow{2}{*}{$\begin{array}{c}\text { Strain } \\
\text { number }\end{array}$} & \begin{tabular}{c} 
FPase \\
\cline { 2 - 5 }
\end{tabular} & $\begin{array}{c}\text { CMCase } \\
(\mathrm{IU} / \mathrm{ml})\end{array}$ & $\begin{array}{c}\beta \text {-Glucosidase } \\
(\mathrm{U} / \mathrm{ml})\end{array}$ & $\begin{array}{c}\text { Xylanase } \\
(\mathrm{U} / \mathrm{ml})\end{array}$ & $\begin{array}{c}\beta \text {-Xylosidase } \\
(\mathrm{U} / \mathrm{ml})\end{array}$ & $\begin{array}{c}\text { Protein } \\
(\mathrm{mg} / \mathrm{ml})\end{array}$ \\
\hline BCC199 & $0.24 \pm 0.01$ & $13.91 \pm 0.03$ & $1.30 \pm 0.00$ & $64.88 \pm 1.54$ & $0.29 \pm 0.02$ & $0.45 \pm 0.04$ \\
AG452 & $0.48 \pm 0.02$ & $13.67 \pm 1.60$ & $6.05 \pm 0.27$ & $37.88 \pm 3.55$ & $1.33 \pm 0.11$ & $0.44 \pm 0.03$ \\
AG496 & $0.53 \pm 0.04$ & $20.16 \pm 1.01$ & $6.03 \pm 0.23$ & $94.55 \pm 4.74$ & $1.56 \pm 0.07$ & $0.53 \pm 0.05$ \\
AG498 & $0.56 \pm 0.03$ & $14.93 \pm 3.08$ & $7.93 \pm 0.25$ & $90.35 \pm 6.59$ & $1.90 \pm 0.04$ & $0.55 \pm 0.03$ \\
AG500 & $0.44 \pm 0.04$ & $15.32 \pm 0.05$ & $0.28 \pm 0.02$ & $40.70 \pm 0.12$ & $0.25 \pm 0.03$ & $0.63 \pm 0.03$ \\
AG548 & $0.50 \pm 0.01$ & $14.90 \pm 0.40$ & $4.10 \pm 0.27$ & $43.38 \pm 2.39$ & $1.10 \pm 0.04$ & $0.48 \pm 0.05$ \\
AG559 & $0.49 \pm 0.03$ & $15.92 \pm 1.41$ & $4.60 \pm 0.49$ & $45.79 \pm 5.47$ & $1.23 \pm 0.12$ & $0.43 \pm 0.03$ \\
\hline
\end{tabular}

Of all strains tested, the P. oxalicum strains AG498 and AG496 exhibited the highest FPase activity of 0.56 and $0.53 \mathrm{IU} / \mathrm{ml}$, respectively, whereas A. aculeatus BCC199 (the reference strain) produced an FPase activity of $0.24 \mathrm{IU} / \mathrm{ml}$. This result was different from the secondary screening result, where AG500 and AG559 were superior in FPase and CMCase secretion. This might be because of the different compositions in the fungal medium. In addition, three strains of P. oxalicum, AG496, AG498, and AG452, produced higher levels of BGL activity than those of the other strains tested in this study. Different strains of $P$. oxalicum have been demonstrated to be excellent cellulase producers for biomass saccharification applications [17, 52]. Additionally, the highest activities of xylanase and $\beta$-xylosidase were also achieved with P. oxalicum (AG496 and AG498), contributing to the potential role of these strains in the production of biomass-degrading enzymes. T. afroharzianum AG500 showed notable FPase and CMCase activities in the secondary screening step; however, it exhibited quite low BGL activity when cultivated in the production medium. It is known that fungal strains of the genus Trichoderma, i.e., T. reesei, produced BGL in small quantities compared to cellobiohydrolase and endoglucanase produced by the same species [46]. It should be noted that BGL activity plays a prominent role in the catalysis of cellobiose into glucose, overcoming cellobiose-mediated repression of cellulases [53]. This might be affected by the further hydrolysis capability of this fungal enzyme.

Pretreatment of Lignocellulosic Substrates and Enzymatic Saccharification Using Crude Enzymes from Cellulolytic Fungi

In this study, various lignocellulosic agro-industrial byproducts, i.e., sugarcane bagasse and trash, cassava pulp and coffee silverskin (a major waste product in the coffee-roasting industry) [54], were collected and used as raw materials for biomass saccharification. Lignocellulose has a complex molecular structure, which can block enzymes and prevent biomass degradation into fermentable sugars. The pretreatment step was performed to remove part of the lignin and hemicellulose and provide easier enzyme accessibility to cellulose $[38,55,56]$. All agro-industrial byproducts were subjected to the two-stage pretreatment process in which the biomass was first treated with diluted sulfuric acid followed by sodium hydroxide pretreatment. The chemical composition of untreated and pretreated lignocellulosic biomasses is illustrated in Table 3. It was clear that the two-stage pretreatment could increase the cellulose proportion and decrease the hemicellulose and lignin contents in lignocellulosic biomasses. The characteristics of lignocellulosic biomass before and after pretreatment are shown in Table S2. Previous studies suggested that the two-stage acid/alkali pretreatment efficiently improved the enzymatic digestibility of the pretreated biomass, resulting in a high conversion yield of fermentable glucose [57, 58].

Then, the potential of the crude enzymes produced by six candidate fungal strains for hydrolysis of the pretreated lignocellulosic biomasses was investigated. As shown in Fig. 4, the enzymes produced by the newly isolated strains were more efficient at hydrolyzing lignocellulosic biomass than BCC199 (the reference strain). Our previous research demonstrated that A. aculeatus BCC199 can produce a multienzyme complex that had high efficiency in the saccharification of alkaline-pretreated rice straw, corn cob, and corn stover [13]. However, the sugarcane bagasse and trash and cassava pulp tested in this study might not be compatible with BCC199 enzymes. This evidence supports the idea that no single-enzyme cocktail will be suitable for all applications [19]. Regarding the glucose yield, the $P$. oxalicum AG452 enzyme showed the highest glucose production of 532.98, 442.87, and $358.10 \mathrm{mg} / \mathrm{g}$ dried substrate (DS), corresponding to approximately $68.17 \%, 78.86 \%$, and $66.84 \%$ cellulose conversion yield when pretreated sugarcane trash, cassava pulp or coffee silverskin were applied as substrates,

Table 3. Chemical composition of untreated and pretreated lignocellulosic biomasses.

\begin{tabular}{lcccccc}
\hline \multirow{2}{*}{ Biomass } & \multicolumn{3}{c}{ Untreated } & \multicolumn{3}{c}{ Pretreated } \\
\cline { 2 - 7 } & Cellulose (\%) & Hemicelluloses (\%) & Lignin (\%) & Cellulose (\%) & Hemicelluloses (\%) & Lignin (\%) \\
\hline Sugarcane bagasse & 35.04 & 29.37 & 18.34 & 74.28 & 13.03 & 4.59 \\
Sugarcane trash & 28.95 & 25.50 & 17.60 & 70.61 & 15.24 & 4.90 \\
Cassava pulp & 20.18 & 13.21 & 18.31 & 50.55 & 9.84 & 19.09 \\
Coffee silverskin & 18.89 & 13.75 & 23.18 & 48.22 & 15.23 & 20.16 \\
\hline
\end{tabular}


A

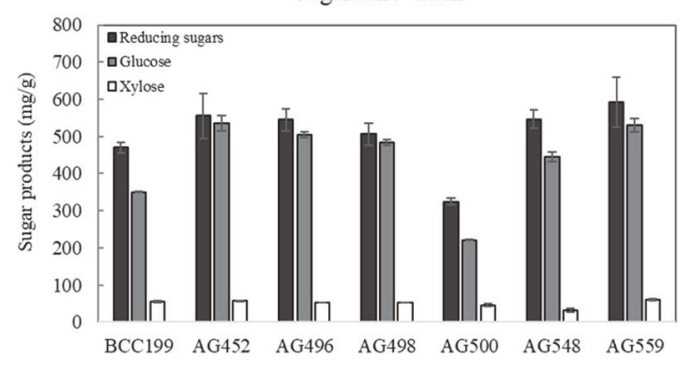

C



B



D

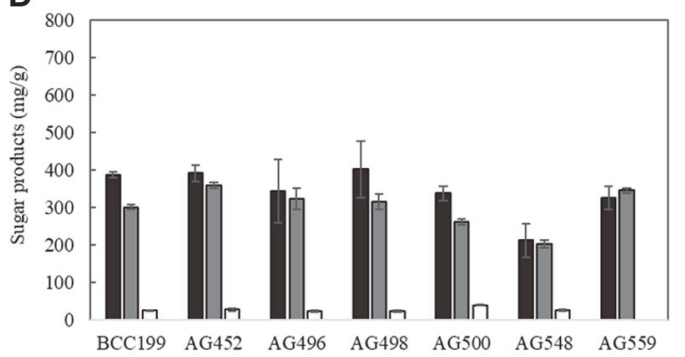

Fig. 4. Enzymatic hydrolysis of pretreated sugarcane trash and bagasse, cassava pulp and coffee silverskin using secreted enzymes from newly isolated fungal strains.

respectively. In contrast to sugarcane bagasse, the use of the Ta. siamensis AG548 enzyme provided the highest glucose yield of $612.20 \mathrm{mg} / \mathrm{g}$ DS, corresponding to a $74.18 \%$ cellulose conversion yield. This evidence reflects the heterogeneity of lignocellulosic substrates, contributing to the optimum enzyme composition. In addition, Visser

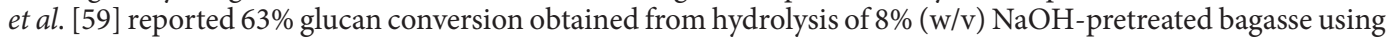
$20 \mathrm{FPU} / \mathrm{g}$ enzyme loading from a coculture of Chrysoporthe cubensis and P. pinophilum. Their conversion yield was less than that of our results when using pretreated bagasse hydrolysis.

Furthermore, after using the pretreated sugarcane trash and bagasse as substrates for hydrolysis, it was found that the reducing sugar and glucose yields were higher than those of pretreated cassava pulp and coffee silverskin. This might be due to the high lignin contents of pretreated cassava pulp and coffee silverskin, causing inhibition of the enzymatic hydrolysis of cellulose [60]. Other pretreatment methods should be applied for further improvement of the enzymatic hydrolysis of such substrates.

\section{Conclusion}

The screening procedure using a miniaturized culture method for screening and selection of naturally isolated fungal strains for cellulase production was demonstrated in this study. The confirming results between a primary screening in 24-well plate culture and a secondary screening in $250-\mathrm{ml}$ shake flasks represent a powerful procedure for our screening strategy. This method can be further applied to large isolation and screening programs of filamentous fungi when aiming to obtain a desired enzyme activity. In addition, this screening method offers direct screening in liquid culture, which is similar to the upscaled industrial production of certain enzymes. Furthermore, the second aim of this study was to find an enzyme suitable for the degradation of agroindustrial wastes, including sugarcane bagasse and trash, cassava pulp and coffee silverskin, the production of which is currently increasing. From the experiment, the P. oxalicum AG452 enzyme was the best fungal strain for saccharification of sugarcane trash, cassava pulp and coffee silverskin. Additionally, Ta. siamensis AG548 was regarded as the best strain for hydrolysis of sugarcane bagasse under our experimental conditions. Fungal strain improvement, i.e., mutagenesis, genetic engineering techniques and bioprocess optimization, are needed to enhance the potential of these strains as onsite cellulase producers.

\section{Acknowledgments}

This work was financially supported by the National Science and Technology Development Agency (Grant no. P1650036).

\section{Conflict of Interest}

The authors have no financial conflicts of interest to declare.

\section{References}

1. Mohanty AK, Misra M, Drzal LT. 2002. Sustainable Bio-Composites from renewable resources: Opportunities and challenges in the green materials world. J. Polym. Environ. 10: 19-26. 
2. Bessou C, Ferchaud F, Gabrielle B, Mary B. 2011. Biofuels, greenhouse gases and climate change. A review. Agron. Sustain. Dev. $31: 1$.

3. Dessie W, Luo X, Wang M, Feng L, Liao Y, Wang Z, et al. 2020. Current advances on waste biomass transformation into value-added products. Appl. Microbiol. Biotechnol. 104: 4757-4770.

4. Tripathi N, Hills CD, Singh RS, Atkinson CJ. 2019. Biomass waste utilisation in low-carbon products: harnessing a major potential resource. NPJ Climate Atmosph. Sci. 2: 35.

5. Lin CY, Eudes A. 2020. Strategies for the production of biochemicals in bioenergy crops. Biotechnol. Biofuels 13: 71.

6. Chandel AK, Garlapati VK, Singh AK, Antunes FAF, da Silva SS. 2018. The path forward for lignocellulose biorefineries: Bottlenecks, solutions, and perspective on commercialization. Bioresour. Technol. 264: 370-381.

7. Kohli K, Prajapati R, Sharma BK. 2019. Bio-Based chemicals from renewable biomass for integrated biorefineries. Energies 12: 233.

8. Vera I, Hoefnagels R, van der Kooij A, Moretti C, Junginger M. 2020. A carbon footprint assessment of multi-output biorefineries with international biomass supply: a case study for the Netherlands. Biofuel. Bioprod. Bior. 14: 198-224.

9. Lugo-Pimentel M, Boboescu I, Beigbeder J-B, Duret X, Wolfaardt F, Ghislain T, et al. 2020. Biorefinery done right. Int. J. Energy Prod. Management 5: 35-47.

10. Yang TC, Kumaran J, Amartey S, Maki M, Li X, Lu F, et al. 2014. Chapter 5 - Biofuels and Bioproducts Produced through Microbial Conversion of Biomass, pp. 71-93. In Gupta VK, Tuohy MG, Kubicek CP, Saddler J, Xu F (eds.), Bioenergy Research: Advances and Applications, Ed. Elsevier, Amsterdam

11. Cianchetta S, Galletti S, Burzi PL, Cerato C. 2010. A novel microplate-based screening strategy to assess the cellulolytic potential of Trichoderma strains. Biotechnol. Bioeng. 107: 461-468.

12. Siqueira JGW, Rodrigues C, Vandenberghe LPD, Woiciechowski AL, Soccol CR. 2020. Current advances in on-site cellulase production and application on lignocellulosic biomass conversion to biofuels: a review. Biomass Bioenerg. 132: 105419

13. Suwannarangsee S, Arnthong J, Eurwilaichitr L, Champreda V. 2014. Production and Characterization of multi-polysaccharide degrading enzymes from Aspergillus aculeatus BCC199 for saccharification of agricultural residues. J. Microbiol. Biotechnol. 24: $1427-1437$.

14. Juturu V, Wu JC. 2012. Microbial xylanases: Engineering, production and industrial applications. Biotechnol. Adv. 30: 1219-1227.

15. Marques NP, Pereira JD, Gomes E, da Silva R, Araujo AR, Ferreira H, et al. 2018. Cellulases and xylanases production by endophytic fungi by solid state fermentation using lignocellulosic substrates and enzymatic saccharification of pretreated sugarcane bagasse. Ind. Crop Prod. 122: 66-75.

16. Contreras F, Pramanik S, Rozhkova AM, Zorov IN, Korotkova O, Sinitsyn AP, et al. 2020. Engineering robust cellulases for tailored lignocellulosic degradation cocktails. Int. J. Mol. Sci. 21: 1589.

17. Jung YR, Park JM, Heo SY, Hong WK, Lee SM, Oh BR, et al. 2015. Cellulolytic enzymes produced by a newly isolated soil fungus Penicillium sp. TG2 with potential for use in cellulosic ethanol production. Renew. Energy 76: 66-71.

18. de Souza MF, da Silva AS, Bon EPS. 2018. A novel Trichoderma harzianum strain from the Amazon Forest with high cellulolytic capacity. Biocatal. Agric. Biotechnol. 14: 183-188.

19. Druzhinina IS, Kubicek CP. 2017. Genetic engineering of Trichoderma reesei cellulases and their production. Microb. Biotechnol. 10: $1485-1499$.

20. Okeke BC, Hall RW, Nanjundaswamy A, Thomson MS, Deravi Y, Sawyer L, et al. 2015. Selection and molecular characterization of cellulolytic-xylanolytic fungi from surface soil-biomass mixtures from black belt sites. Microbiol. Res. 175: 24-33.

21. Coughlan MP. 1985. The properties of fungal and bacterial cellulases with comment on their production and application. Biotechnol. Genet. Eng. Rev. 3: 39-110.

22. Dashtban M, Schraft H, Qin WS. 2009. Fungal bioconversion of lignocellulosic residues; opportunities \& perspectives. Int. J. Biol. Sci. 5: $578-595$

23. Kasana RC, Salwan R, Dhar H, Dutt S, Gulati A. 2008. A rapid and easy method for the detection of microbial cellulases on agar plates using gram's iodine. Curr. Microbiol. 57: 503-507.

24. Alberto F, Navarro D, de Vries RP, Asther M, Record E. 2009. Technical advance in fungal biotechnology: development of a miniaturized culture method and an automated high-throughput screening. Lett. Appl. Microbiol. 49: 278-282.

25. Beneyton T, Wijaya IPM, Postros P, Najah M, Leblond P, Couvent A, et al. 2016. High-throughput screening of filamentous fungi using nanoliter-range droplet-based microfluidics. Sci. Rep. 6: 27223.

26. Linde T, Hansen NB, Lubeck M, Lubeck PS. 2014. Fermentation in 24-well plates is an efficient screening platform for filamentous fungi. Lett. Appl. Microbiol. 59: 224-230.

27. Shin WS, Lee D, Kim S, Jeong YS, Chun GT. 2017. Development of miniaturized culture systems for large screening of mycelial fungal cells of Aspergillus terreus producing itaconic acid. J. Microbiol. Biotechnol. 27: 101-111.

28. Mandels M, Weber J. 1969. The Production of Cellulases, pp. 391-414. Cellulases and Their Applications, Ed. American Chemical Society

29. Chuaseeharonnachai C, Suetrong S, Nuankaew S, Somrithipol S, Hongsanan SN, Srikitikulchai P, et al. 2020. Synnematotriadelphia gen. nov. (S. stilboidea comb. nov. and S. synnematofera comb. nov.) and Triadelphia hexaformispora sp. nov. in the family Triadelphiaceae. Mycol. Prog. 19: 127-137.

30. White, Bruns T, Lee S, Taylor J. 1990. White, T. J., T. D. Bruns, S. B. Lee, and J. W. Taylor. Amplification and direct sequencing of fungal ribosomal RNA Genes for phylogenetics, pp. 315-322. Ed.

31. Rehner SA, Buckley E. 2005. A Beauveria phylogeny inferred from nuclear ITS and EF1-alpha sequences: evidence for cryptic diversification and links to Cordyceps teleomorphs. Mycologia 97: 84-98.

32. Liu YJ, Whelen S, Hall BD. 1999. Phylogenetic relationships among ascomycetes: evidence from an RNA polymerse II subunit. Mol. Biol. Evol. 16: 1799-1808.

33. Hong SB, Go SJ, Shin HD, Frisvad JC, Samson RA. 2005. Polyphasic taxonomy of Aspergillus fumigatus and related species. Mycologia 97: 1316-1329.

34. Glass NL, Donaldson GC. 1995. Development of primer sets designed for use with the PCR to amplify conserved genes from filamentous ascomycetes. Appl. Environ. Microbiol. 61: 1323-1330.

35. Boonyuen N, Chuaseeharonnachai C, Suetrong S, Sri-Indrasutdhi V, Sivichai S, Jones EBG, et al. 2011. Savoryellales (Hypocreomycetidae, Sordariomycetes): a novel lineage of aquatic ascomycetes inferred from multiple-gene phylogenies of the genera Ascotaiwania, Ascothailandia, and Savoryella. Mycologia 103: 1351-1371.

36. A.Hall T. 1999. BioEdit: a user-friendly biological sequence alignment editor and analysis program for Windows 95/98/NT. Nucleic Acids Symposium Series 41: 95-98

37. Saini R, Saini JK, Adsul M, Patel AK, Mathur A, Tuli D, et al. 2015. Enhanced cellulase production by Penicillium oxalicum for bioethanol application. Bioresour. Technol. 188: 240-246.

38. Maeda RN, Barcelos CA, Anna LMMS, Pereira N. 2013. Cellulase production by Penicillium funiculosum and its application in the hydrolysis of sugar cane bagasse for second generation ethanol production by fed batch operation. J. Biotechnol. 163: 38-44.

39. Sluiter A, Hames B, Scarlata C, Sluiter J, Templeton D, Crocker D. 2008. Determination of Structural Carbohydrates and Lignin in Biomass-NREL/TP-510-42618. Laboratory Analytical Procedure (LAP).

40. Miller GL. 1959. Use of Dinitrosalicylic Acid Reagent for Determination of Reducing Sugar. Anal. Chem. 31: 426-428. 
41. Ghose TK. 1987. Measurement of cellulase activities. Pure Appl. Chem. 59: 257-268.

42. Singhania RR, Adsul M, Pandey A, Patel AK. 2017. 4 - Cellulases, pp. 73-101. In Pandey A, Negi S, Soccol CR (eds.), Current Developments in Biotechnology and Bioengineering, Ed. Elsevier.

43. Chundawat SPS, Balan V, Dale BE. 2008. High-throughput microplate technique for enzymatic hydrolysis of lignocellulosic biomass. Biotechnol. Bioeng. 99: 1281-1294.

44. Walter ME, Ortiz A, Sondgeroth C, Sindt NM, Duszenko N, Catlett JL, et al. 2016. High-throughput mutation, selection, and phenotype screening of mutant methanogenic archaea. J. Microbiol. Methods 131: 113-121.

45. Inoue H, Decker SR, Taylor LE, Yano S, Sawayama S. 2014. Identification and characterization of core cellulolytic enzymes from Talaromyces cellulolyticus (formerly Acremonium cellulolyticus) critical for hydrolysis of lignocellulosic biomass. Biotechnol. Biofuels 7: 151 .

46. Tiwari P, Misra BN, Sangwan NS. 2013. Beta-glucosidases from the fungus Trichoderma: an efficient cellulase machinery in biotechnological applications. Biomed. Res. Int. 2013: 203735.

47. de Hoog GS. 1996. Risk assessment of fungi reported from humans and animals. Mycoses 39: 407-417.

48. Premalatha N, Gopal NO, Jose PA, Anandham R, Kwon SW. 2015. Optimization of cellulase production by Enhydrobacter sp ACCA2 and its application in biomass saccharification. Front. Microbiol. 6: 1046.

49. Manisha, Yadav SK. 2017. Technological advances and applications of hydrolytic enzymes for valorization of lignocellulosic biomass. Bioresour. Technol. 245: 1727-1739.

50. Yao GS, Li ZH, Gao LW, Wu RM, Kan QB, Liu GD, et al. 2015. Redesigning the regulatory pathway to enhance cellulase production in Penicillium oxalicum. Biotechnol. Biofuels 8: 71.

51. Picart P, Diaz P, Pastor FIJ. 2007. Cellulases from two Penicillium sp strains isolated from subtropical forest soil: production and characterization. Lett. Appl. Microbiol. 45: 108-113.

52. Jing L, Zhao S, Xue JL, Zhang Z, Yang Q, Xian L, et al. 2015. Isolation and characterization of a novel Penicillium oxalicum strain Z13 with enhanced cellobiohydrolase production using cellulase-hydrolyzed sugarcane bagasse as carbon source. Ind. Crop Prod. 77: 666-675.

53. Singhania RR, Patel AK, Sukumaran RK, Larroche C, Pandey A. 2013. Role and significance of beta-glucosidases in the hydrolysis of cellulose for bioethanol production. Bioresour. Technol. 127: 500-507.

54. Hijosa-Valsero M, Garita-Cambronero J, Paniagua-Garcia AI, Diez-Antolinez R. 2018. Biobutanol production from coffee silverskin. Microb. Cell Fact. 17: 154.

55. Sun Y, Cheng JY. 2002. Hydrolysis of lignocellulosic materials for ethanol production: a review. Bioresour. Technol. 83: 1-11.

56. Zhang YHP, Lynd LR. 2004. Toward an aggregated understanding of enzymatic hydrolysis of cellulose: noncomplexed cellulase systems. Biotechnol. Bioeng. 88: 797-824.

57. Weerasai K, Suriyachai N, Poonsrisawat A, Arnthong J, Unrean P, Laosiripojana N, et al. 2014. Sequential acid and alkaline pretreatment of rice straw for bioethanol fermentation. Bioresources 9: 5988-6001.

58. Li P, Cai D, Zhang CW, Li SF, Qin PY, Chen CJ, et al. 2016. Comparison of two-stage acid-alkali and alkali-acid pretreatments on enzymatic saccharification ability of the sweet sorghum fiber and their physicochemical characterizations. Bioresour. Technol. 221: 636-644.

59. Visser EM, Falkoski DL, de Almeida MN, Maitan-Alfenas GP, Guimaraes VM. 2013. Production and application of an enzyme blend from Chrysoporthe cubensis and Penicillium pinophilum with potential for hydrolysis of sugarcane bagasse. Bioresour. Technol. 144: $587-594$

60. Pan XJ. 2008. Role of functional groups in lignin inhibition of enzymatic hydrolysis of cellulose to glucose. J. Biobased. Mater. Bioenergy 2: 25-32. 